\title{
Age of the Living Dead: Personality Rights of Deceased Celebrities
}

\section{DAVID COLLINS*}

This article examines the legal issues arising from digital technology that allows filmmakers to create features starring flawlessly rendered images of deceased celebrities, known as "synthespians." Recent developments in the law of personality rights in California have established that deceased stars' personality rights extend beyond death, permitting heirs to seek damages for wrongful uses. In Canada the tort of misappropriation of personality has been extended after death both at common law and in the privacy acts of some provinces. This article examines instances where courts have ruled against uses, often where there has been commercial exploitation, of the dead actor's persona and concludes with recommendations on strategies 10 regulate this area of the law.
Cet article se penche sur les questions juridigues résultant de la technologie numérique qui permet aux cinéastes de produire des clips montrant des images parfaites de vedettes décédées, appelées "synthespians ". Les derniers développements dansle domaine des droits de la personnalité en Californie ont établi que les droits de la personnalité d'une vedelte décédée demeurent en place après sa mort, permettant ainsi aux héritiers de réclamer des dommages-intérêts pour usage fautif. Au Canada. le délit d'usurpation d'identité se maintient après la mort dans le droit commun el dans les lois sur la protection desrenseignements personnels decertaines provinces. Cet article se penche sur des cas où les tribunaux ont interdit l'utilisation de l'identité d'un acteur décédé, souvent dans le cas d'une exploitation commerciale, et se termine avec des recommandations de stratégies visant à réglementer cet aspect de la loi.

\section{TABLE OF CONTENTS}

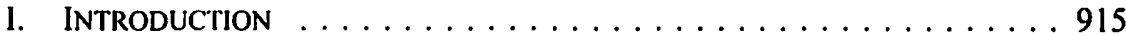

II. DigITAL ACTORS . . . . . . . . . . . . . . . . . . . 915

III. AMERICAN RIGHT OF PUBLICITY FOR DECEASED PERSONS . . . . . . 917

A. COMMON LAW . . . . . . . . . . . . . . 917

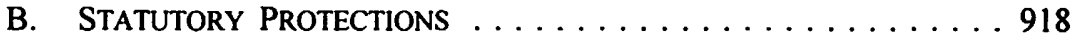

IV. CANAdIAN COMMON LAW ................. 921

A. MISAPPROPRIATION OF PERSONALITY .......... 921

B. POST-MORTEM RIGHTS . . . . . . . . . . . . . . . . . . . . . . 923

V. CANADIAN STATUTORY PROTECTION FOR

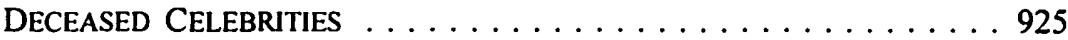

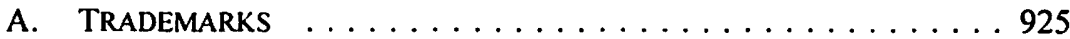

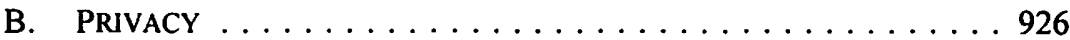

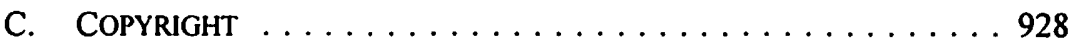

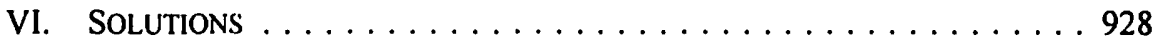

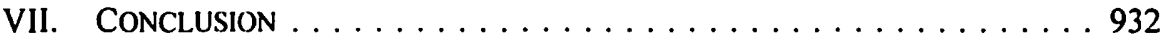

B.A. Hons., J.D. (University of Toronto). Called to the Bar of Ontario in 2001, Associate at Fleury, Comery LLP, Toronto, Ontario. The author would like to thank the editors of the Alberta Law Review for their editorial assistance. 


\section{INTRODUCTION}

Advances in digital technology may soon allow computer-generated actors, called "synthespians," to become the biggest stars in Hollywood. Many commentators have already recognized the fantastic potential in resurrecting deceased celebrities to star in new films without the big salaries, the hassle of script approval, or the annoyance of airconditioned trailers and personal trainers. ${ }^{2}$ More than this, the interaction of modern stars with those of past eras could create tremendous drama. Still, while there are wondrous cinematic possibilities in the digital reanimation of dead actors, there are numerous legal problems that must be addressed before the first ghost is brought back to life.

This article discusses one of the most contentious new issues in intellectual property law: the post-mortem right of publicity. In Canada the tort of misappropriation of personality has already been applied to advertising. It may soon apply to digitally resurrected actors. We will see that there is a movement, both in common law and in statute, to recognize that these rights continue after death. This article examines some of the solutions that have been proposed to address the conflict, balancing the interests of an actor's estate and the creativity of filmmakers. We begin by taking a closer look at the phenomenon of digital imaging in movies.

\section{Digital Actors}

Beginning in films like Alien $^{3}$ and Tron, ${ }^{4}$ digital computer animation was becoming among the most popular special effects of the 1980s. In 1985 the first completely digital character appeared in The Young Sherlock Homes, ${ }^{\text {s }}$ and by 1991, Terminator 2: Judgment $D a y^{6}$ featured a complex digital character with extensive screen time. By 1996 over 50 percent of all feature films used some kind of digital effect.' Digital characters can be either two-dimensional, which involves the manipulation of existing photographs or film footage, ${ }^{8}$ or three-dimensional where a complete three-dimensional copy of a character is created that has no independent existence outside of the computer. This was done perhaps

1 J.E. Weinstein, "Abbott and Costello Meet Frankenstein, Dracula and the Wolf Man in the Year 2000 or the Birth of the Synthespian" in J.D. Viera, R. Thorne \& S.F. Breimer, eds., Entertainment. Publishing and the Arts Handbook 1998-1999 Edition (St. Paul, MN: West Group, 1998) 257 at 257 58.

$2 \quad$ E. Giacoppo, "Avoiding the Tragedy of Frankenstein: The Application of the Right of Publicity to the Use of Digitally Reproduced Actors in Film" in J.D. Viera, R. Thorne \& S.F. Breimer, eds., Entertainment, Publishing and the Arts Handbook 1998-1999 Edition (St. Paul, MN: West Group, 1998) 225 at 226.

20th Century Fox, 1979.

Walt Disney, 1982.

Paramount Pictures, 1985. See Nova On-Line: <www.pbs.org/wgbh/nova/specialfx2/1980.html> (date accessed: 28 June 2001).

Universal Pictures, 1991.

T.G. Martin Jr., "Rebirth and Rejuvenation In a Digital Hollywood: The Challenge ComputerSimulated Celebrities Present for California's Antiquated Right of Publicity" (1996) 4 U.C.L.A. Ent. L. Rev. 99 at 107.

* As in Forrest Gump (Paramount Pictures, 1994) when Tom Hanks meets President Kennedy. See Giacoppo, supra note 2 at 229. 
most notably in Star Wars: The Special Edition ${ }^{9}$ where a digital creature was created to interact with decades-old footage of Harrison Ford. ${ }^{10}$ A combination of these two techniques may be employed to create lifelike, moving charactersthat are indistinguishable from real actors.

More impressively, this technique may lead to the creation of non-existent actors that could be designed to suit any role." More importantly, for the purposes of this discussion, the technology could use photographs of deceased actors to have them star in new movies. A similar, less advanced method has already been used to insert Marilyn Monroe and Humphrey Bogart into a seven-minute short film Rendezvous a Montreal in 1987 by Swiss scientists Daniel and Nadia M. Thalmann. ${ }^{2}$ Similarly, a Diet Coke advertisement altered archived footage of Humphrey Bogart, James Cagney, and Louis Armstrong. ${ }^{13}$

The possibilities of digital animation are clearly astounding. An actor could license his digital likeness from different stages of his career, or even auction off the rights to his likeness in order to enjoy the benefits during his lifetime. ${ }^{14}$ Indeed, anticipating developments in digital technology, Marlon Brando, among other actors, had his face digitally scanned and saved for future use. ${ }^{15}$ Moreover, insurance companies could require actors to be digitally duplicated in order to finish a film's physical production if the actor died during filming ${ }^{16}$ Such a situation happened to complete some of the scenes from The Crow, ${ }^{17}$ during the filming of which actor Brandon Lee died. ${ }^{18}$ The rapidly expanding Canadian film industry requires Canadian lawyers to take a close look at the issues this phenomenon will raise.

Unfortunately, or perhaps fortunately for lawyers, this wondrous technology may infringe on the deceased celebrity's publicity rights, or in Canada cause the tort of misappropriation of personality. If such publicity/personality rights are descendable, meaning they can be transferred to living relatives, there will be an injured party who can seek damages. Without post-mortem rights, the actor's likeness will belong to the public domain after death, allowing for carte blanche in digital reproductions. While the

20th Century Fox, 1997.

Giacoppo, supra note 2 at 229.

J.J. Beard, "Virtual Actors Create Real IP Headaches" Part I: (1998) 219:68 N.Y.L.J. 5 \& Part II: (1998) $219: 73$ N.Y.L.J. 5. Beard reports that James Cameron plans to make a feature film with a digital lead.

Giacappo, supra note 2 at 231.

Ibid. Recently Martin Luther King Jr. was added to a commercial for Alcatel, a communication company, using George Lucas' company Industrial Light and Magic (P. Farhi, "Martin Luther King turned into TV pitchman" The Toronto Star (29 March 2001) A11).

Martin Jr., supra note 7 at 101.

Giacoppo, supra note 2 at 232.

Martin Jr., supra note 7 at 129.

Miramax, 1993.

Giacoppo, supra note 2 at 231 . This is preferential to the disastrous result that occurred in the past when substitute actors were used to complete scenes. Ironically, a replacement was used for Bruce Lee, Brandon Lee's father, in The Game of Death (Paragon Films, 1977) who looked embarrassingly unlike Lee. 
technology is not yet perfect, it can be only a few years away. ${ }^{19}$ It is for this reason that Parliament should establish intellectual property laws, and the provinces tort regimes, that can deal with the inevitable conflicts of tomorrow. To illustrate how this might be done, it is important to consider the American right of publicity for deceased persons and crucial recent developments in California.

\section{American Right of Publicity for Deceased Persons}

\section{A. COMmON LAW}

American courts, which have naturally been more sensitive to the cause of celebrity, have established a "right of publicity" in a person's likeness, which protects it from commercial exploitation by a third party. However, as one commentator has said, "the right of publicity doctrine is a vague and murky body of law, and the ambiguity of precedent opens the door for permitting the unauthorized cloning of a personality." 20 Still, American case law has shown that the right of publicity is a species of property that exists independently of privacy, ${ }^{21}$ and consequently, there is a good deal of room for courts to expand this law: "courts are not bound by principles applicable [to privacy law] but are free to determine the parameters of the right of publicity by analogy to the laws of property, privacy, copyright, and other areas."22 The first American case to discuss the inheritability of publicity was Price v. Hal Roach Studios Inc. ${ }^{23}$ where the use of the name and likenesses of Laurel and Hardy was challenged by Hardy's widow. The Court held that death did not extinguish the right.

Since then American courts have adopted one of three views relating to post-mortem personality rights. First, the right is not descendable to the deceased person's estate, so the likeness falls into the public domain at death. Second, the right descends on the condition that the individual exploited the right while living. Third, the right descends irrespective of whether the individual exploited the right during his or her lifetime. ${ }^{24}$ This last perspective holds that the law would unfairly prejudice someone who had died a short time after becoming a celebrity or who did not have the time to use fully his or her star status. While some commentators hold that exploitation of one's fame during life must be a prerequisite ${ }^{25}$ many disagree ${ }^{26}$ because otherwise the law would unfairly prejudice someone who died a short time after becoming famous or who did not have the time to make full use of his or her celebrity status. ${ }^{27}$

Giacoppo, supra note 2 at 231 .

P.L. Kunath, "Lights, Camera, Animate! The Right of Publicity's Effect on Computer Animated Celebrities" (1996) 29 Loy. L.A. L. Rev. 863 at 896.

See Zacchini v. Scripps-Howard Broadcasting Co., 433 U.S. 562 (1977).

B.C. Adams, "Inheritability of the Right of Publicity Upon the Death of the Famous" (1980) 33

Vand. L. Rev. 1251 at 1255.

400 F.Supp. 863 (S.D.N.Y. 1975).

Giacoppo, supra note 2 at 237.

P.L. Felcher \& E.L. Rubin, "The Descendibility of the Right of Publicity: Is There Commercial Life After Death?" (1979-80) 89 Yale L.J. 1125 at 1131.

Adams, supra note 22 at 1263 .

Ibid. 
In keeping with this last view, the majority of American states do not require exploitation during the actor's lifetime to find that publicity has been infringed. ${ }^{28}$ However, at least one district, Utah, requires commercial exploitation during lifetime. ${ }^{29}$ But as commentator Rachel Healey Huffstetler claims, "the modern view is that the right of publicity does survive the death of its owner and commercial exploitation is unnecessary. ${ }^{30}$ Several American states now recognize a post-mortem right of publicity through either the common law or statute. Many more courts around the United States have had cause to interpret these statutes. ${ }^{31}$

California's treatment of the right is naturally the most crucial as it is the centre of the film and entertainment industry. Many commentators believe that other states, and other nations, may well look to California for guidance in developing their publicity statutes. ${ }^{32}$ California, oddly enough, does not recognize post-mortem rights of publicity at common law. In the famous case Lugosi v. Universal Pictures, ${ }^{33}$ the California Supreme Court held that the right to exploit Lugosi's name and likeness in the context of his role as Dracula did not descend, in part because Lugosi did not exploit his identity for commercial gain during his lifetime. More importantly, Lugosi was portraying a classic character from a novel and did not possess any property rights in the character. Consequently, Lugosi's identity as Dracula did not descend to his heirs.

\section{B. Statutory Protections}

As the centre of film production in the United States has always been California, the most important statutory protection for deceased celebrities should remain the California Civil Code.$^{34}$ The current $A c t$ does not define the term "likeness"; however, a computer-

See Martin Luther King Jr., Center for Social Change, Inc. v. American Heritage Products, Inc. 694 F.2d 674 (11th Cir. 1983).

See Nature's Way Products, Inc. v. Nalure-Pharma, Inc. 736 F.Supp 245 (D. Utah 1990).

R.H. Huffstetler, "An Immortal Image" (December 1998) IP Magazine at 5, online: <www.ipcenter.ipmag.com/98-dec/huffstet.html> (date accessed: 14 May 1999).

J. Barge. "Deceased Stars Haunting the Courtroom" (1995) 81 A.B.A.J. 33(2) at 33.

Giacoppo, supra note 2 at 227.

24 Cal.Rptr.3d 813 (Sup. Ct. 1979).

Cal. Civ. Code $\$ 3344.1$ (West Supp. 2001). The California Civil Code provides, in relevant part: (a)(1) Any person who uses a deceased personality's name, voice, signature, photograph, or likeness, in any manner, on or in products, merchandise, or goods, or for the purposes of advertising or selling, or soliciting purchases of, products, merchandise, goods, or services, without prior consent from the person ... shall be liable for any damages sustained by the person or persons injured as a result thereof...

h) As used in this section "deceased personality" means any natural person whose name, voice, signature, photograph or likeness has commercial value at the time of his or her death...

(h)(i) As used in this section "photograph" means any photograph or photographic reproduction, still or moving, or any video tape or live television transmission, of any person. such that the deceased personality is readily identifiable...

(n) This section shall not apply to the use of a deceased personality's name, voice, signature. photograph or likeness. in any of the following instances: (1) A play, book, magazine, newspaper. musical composition, film, radio or television program, other than an advertisement or commercial announcement not exempt under paragraph (4); (2) material that is of political or newsworthy value; (3) Single and original works of fine art; (4) an advertisement or commercial announcement for a use permitted by (1), (2), or (3) [hereinafter Code]. 
generated actor would probably have even fit under a narrow reading of this term as the process of rendering the character is very similar to photographic techniques, which are defined in the statute. ${ }^{35}$ A mechanical robot was considered a "likeness" of Vanna White even though it was not an exact replica, and a "look-alike" of Jackie Onassis was also considered an infringing likeness. ${ }^{36}$

Also problematic are the numerous exemptions, in both the current and the earlier California Code, to the prohibition against using a celebrity without consent. Plays, books, magazines, newspapers, films, and TV programs were all exempt uses. ${ }^{37}$ Some felt that these exceptions were unnecessary as the American First Amendment right to free speech would outweigh an individual's right of publicity anyway. ${ }^{38}$ However, others, such as commentator Thomas Glenn Martin Jr., concluded that the exemptions to the s. 990 right were too broad, such that only flagrant violations such as celebrities' faces on coffee mugs or T-shirts would be violative. ${ }^{39}$ With the hope of preserving artists' ability to be creative in the realm of biographies and other historical projects using the deceased celebrity, the law had essentially left the celebrity's estate without protection. Martin argued that a more flexible approach to the exemptions should be applied in the future, which takes into account the extent of creativity the user of the digital actor has put into the work:

\footnotetext{
Rather than grant film and television programs per se exemptions, a court should make an inquiry into the nature of the defendant's use of the deceased personality's identity.... If the defendant's use ... is simply exploitative and adds little to the defendant's overall creative contribution, then a court should find that such use is unprotected. However, if the defendant's use is an integral part of a work that includes significant contribution of the defendant's own creativity, then a court should protect the use. ${ }^{40}$
}

This balancing of creativity and contribution would be an extremely difficult task for any court. While not addressing the California Code, perhaps the best example of this weighing of creative value can be found in Presley's Estate v. Russen. ${ }^{41}$ There the Court found that the project's "contribution to society's cultural enrichment" would be a factor to consider when deciding creative merit of a digital actor's appearance. Naturally, this would be extremely difficult to assess. However, some commentators think that a more policy-oriented analysis is the best way to ultimately adjudicate the issue of post-mortem publicity rights as it avoids "deceptive certainty and the overly conclusive nature" of strict categorization. $^{42}$

Giacoppo, supra note 2 at 244. Giacoppo discusses an earlier version of the California Code $\$ 990$ $\$ 3344$ (West Supp. 1997) that, in addition to lacking a definition of "likeness," also made no mention of deceased celebrities.

White v. Samsung Electronics America. Inc. 971 F.2d 1395 (9th Cir. 1992) [hereinafter White]; and Onassis v. Christian Dior, 472 N.Y.S. (2d) 254 (Sup. Ct. 1984) [hereinafter Onassis].

Code, supra note $34, \S(1) n$. See also Giacoppo, supra note 2.

Kunath, supra note 20 at 884.

Martin Jr., supra note 7 at 119

Ibid. at 130.

513 F.Supp. 1339 (Dist. Ct. N.J. 1981).

Felcher \& Rubin, supra note 25 at 1128. 
The decision of Astaire v. Best Film \& Video Corp. ${ }^{43}$ has had the most far-reaching effect on the development of deceased publicity rights, leading to California's 1999 enactment of the Astaire Celebrity Protection Act. ${ }^{44}$ Interestingly, the Astaire case actually threatened the descendability of publicity rights in the United States ${ }^{45}$ In Astaire the defendant had used a digitally recreated Fred Astaire to sell instructional dance videotapes, without the permission of Astaire's estate. The Court dismissed the California Civil Code s. 990 claim, in part because the videotapes fell under the film exemption, and also because of the lack of abuse or ridicule of Astaire. Still, some felt that the mere fact that the defendants increased the marketability of their product without compensating Astaire's estate should have been enough to warrant a s. 990 violation. ${ }^{46}$

However, the conflict between creative freedom and the rights of the celebrity arising from the Astaire decision led to the aforementioned Celebrity Protection Act which now amends and renumbers s. 990 of the California Civil Code enlarging protection for deceased celebrities' rights in two main ways. First, the Act extends the post-mortem right of publicity from 50 to 70 years following death. ${ }^{47}$ Second, and perhaps more importantly, standing will exist to bring an action under the Act regardless of whether the descendants were domiciled in California at the time of the celebrity's death, which California law did not permit, as it allowed only the law of the jurisdiction where the personal property was located to govern. ${ }^{48}$ Now all that is required is that some violation of the statute occur in the state. This amendment was brought about by the Cairns v. Franklin Mint $\mathrm{Co}^{49}$ case where Princess Diana's likeness was used without permission, but her family failed in their claim because they lacked California residency. ${ }^{50}$ Like its predecessor, the Celebrity Protection Act retains exemptions for entertainment, drama, literary or musical works, illustrating that the $A c t$ was designed to prevent commercial exploitation only. This has pleased the Motion Picture Association of America greatly."

There remains significant debate over which uses will be exempt. Commentator Erin Giacoppo believes that if the replica is one aspect of a larger, original artistic work and is not exploitative, the First Amendment will protect it. ${ }^{52}$ Joseph Beard believes that a court must consider three factors: 1) the type of work; 2 ) the type of celebrity (performer

I16 F.3d 1297 (9th Cir. 1997) amended by 136 F.3d 1208 (9th Cir. 1998) [hereinafter Astaire]. 1999 Cal. Sta. Ch. 998. This $A c t$ is more formally known as the Cal. Civ. Code $\$ 3344.1$, supra note 34 [hereinafter Celebrity Protection Act].

P.H. Yu, "Astaire v. Best Film \& Video Corp" (1998) 13 Berk. Tech. L.J. 319 at 320.

lbid. at 343.

J.J. Beard, "Fresh Flowers for Forest Lawn: Amendment of the California Post-Mortem Right of Publicity Statute" (2000) 17 Ent. \& Sports L. 22 at 23. Beard believes this extension from 50 years is meant to mirror the 70 years following death protection of the Sonny Bono Copyright Term Extension Act of 1998, 112 Stat. 2827 (1998). Note also that post-mortem rights of publicity are 100 years in Indiana and Oklahoma. See Ind. Stat. $\$ 32-12-1$ et seq. (West Supp. 1993) and Okla. Stat. Ann. tit. $12 \$ 1448$ supp. et seq. (West Supp. 1993).

Beard, ibid, at 24.

24 F.Supp.2d 1013 (C.D. Cal. 1998).

This case will soon be retried under the new Celebrity Protection Act and reversal is likely. Beard, supra note 47 at 24.

Ibid. at 25 .

Giacoppo, supra note 2 at 242. 
or non-performer) and 3) the type of role (factual or fictional). Beard claims that a freedom of expression argument is best suited to factual works in which a deceased nonperformer appears as himself. Accordingly, where a deceased performer plays a fictional character in a new entirely fictional work, the First Amendment justification will carry less weight. ${ }^{53}$ Beard fails to explain what he means by "type of work" and his distinction in treatment of performer and non-performer is problematic. It does not follow that a celebrity, such as an actor, has any more right to profit from his likeness than another celebrity, such as a politician. If anything, a deceased politician might deserve more protection, and his family more compensation, as both the politician and his family were unable to financially profit from fame during their lives. Politicians are much less likely, and in fact probably prohibited in some cases, from endorsing products, an activity open to actors.

Crucial to the battle between creativity and actors' rights is the notion that celebrities should only be protected against commercial uses. If this is true, then we are compelled to determine exactly what makes a use commercial. Commentator Pamela Lynn Kunath holds that an actor's appearance in the context of a narrative feature film is a noncommercial use. Her reasoning seems to mirror that of the Astaire court. Since the actor is actually an integral part of the project, i.e., he stars in the film that he also happens to advertise, then his presence is not truly a commercial purpose. Consequently, the use of a celebrity to promote a film in which she does not appear would be a commercial use..$^{54}$

\section{Canadian Common law}

\section{A. Misappropriation of Personality}

Film companies may compel Canadian advertising agencies and film producers to negotiate for the personality rights of their stars under California terms as a condition of licensing film rights. ${ }^{55}$ As such, it is essential to be mindful of California laws when dealing with any kind of celebrities' rights in Canada or anywhere else in the world. Still, Canadian law has its own version of the "right of publicity," and has similarly begun to recognize the rights of deceased personalities in some jurisdictions.

Canada has employed the tort of "misappropriation of personality" as the primary method of protecting publicity rights of celebrities. ${ }^{56}$ The tort originated in Krouse v. Chrysler Canada $\mathrm{Ltd}^{57}$ where a football player sued the car company Chrysler for using his photograph in an advertisement without his permission. The Court did not find an action for passing off, largely because the player did not expressly or even implicitly

Beard, supra note 47 at 27.

Kunath, supra note 20 at 882 and 887.

ss

B. Pritchard, "Wanted: Personalities - Dead or Alive" (Entertainment, Advertising and Media Law Conference, Osgoode Hall, 23 \& 24 February 1996) Dept. of Continuing Education, Law Society of Upper Canada (1996) I at 13.

s. R.G. Howell, "Publicity Rights In the Common Law Provinces of Canada" (1998) 18 Loy L.A. Ent. L.J. 487.

37 (1973), 40 D.L.R. (3d) 15 (Ont. C.A.) [hereinafter Krouse]. 
endorse the product and there was no intent to misappropriate his personality. Furthermore, there was an insufficient nexus between the product supposedly being endorsed and Krouse's identity, possibly because Krouse was not a particularly wellknown player. Still, the Court recognized a need for the protection of one's personality and the tort was born. ${ }^{58}$ Careful to reiterate that no claim was made under conventional intellectual property principles, Estey J.A. as he then was, concluded for the Court "the common law does contemplate a concept in the law of torts which may be broadly classified as an appropriation of one's personality." 59

Krouse was followed in Athans v. Canadian Adventure Camps Ltd. ${ }^{60}$ where the use of an image of a famous water skier without consent was viewed as an invasion of the plaintiff's right to market his personality. ${ }^{61}$ The Court in Athans established that in order to ground an action in misappropriation of personality the advertisement must clearly identify the plaintiff, the plaintiff must clearly have been "used" to advertise, there must be damage or unjust enrichment, and no public interest reason to prevent it. ${ }^{62}$ Accordingly, the Athans judge decided that the advertisement was an invasion of Athan's exclusive right to market his personality. It is significant that the doctrine of "passing off" was explicitly rejected in both Krouse and Athans. This may be positive from the point of view of celebrities, as passing off necessitates a common field of activity, the test for which seems to be fairly strict in Canadian courts. ${ }^{63}$

In addition to the common law jurisdictions of Canada, the Quebec Superior Court has recognized the right to one's image as an aspect of property in Deschamps v. Renault Canada $^{64}$ where film footage of celebrities was used to advertise cars without their permission. Descendability of the right was not addressed in that case.

American celebrities have sought protection under the Canadian tort for unauthorized use of their personalities in advertisements in Canada. Burt Reynolds hired a Canadian lawyer when a Reynolds look-alike was used in an advertisement, but the matter was settled before trial when the defendant claimed the look-alike had as much of a right to market his appearance as Reynolds did. ${ }^{65}$ In the late 1980 s, James Cagney retained Canadian counsel when a still from the 1931 film Public Enemy, which had fallen into the public domain, was used to advertise breath mints. Again the matter was settled without litigation. The singer Chubby Checker also tried to use the tort in relation to a sound-alike television advertisement for McDonald's twisty french fries. ${ }^{66}$

5k Howell, supra note 56 at 492.

31) Krouse, supra note 57 at 28.

(1) (1977), 80 D.L.R. (3d) 583 (Ont. H.C.J.) [hereinafter Athans].

(1) See also Racine v. C.J.R.C. Radio Capitale Liée. (1977), 17 O.R. (2d) 370 (Co. Ct.); Healh v. WeistBarron School of Television Canada Ltd. (1981), 34 O.R. (2d) 126 (H.C.J.); and Dowel v. Mengen Institute (1983), 72 C.P.R. (2d) 238 (Ont. H.C.J.).

62 Pritchard, supra note 55 at 3.

6.3 Howell, supra note 56 at 491. See for example, Ciba-Geigy Canada v. Apotox Inc., [1992] 3 S.C.R. 120.

w (24 February 1972), Montreal 05-810-140-71 in "Jugements" (1977) 18 C. de D. 937.

is Pritchard, supra note 55 at 10 . Contrast this with the Onassis case, supra note 36 , which held use of a look-alike to be a violation. 


\section{B. POST-MORTEM RIGHTS}

While misappropriation of personality is established in law, there have only been two Canadian cases that have dealt with the assertion of personality rights by the estate of a dead celebrity. Gould Estate v. Stoddart Publishing $\mathrm{Co}^{67}$ addressed the use of photographs of Glenn Gould, which were included in an unauthorized biography of the deceased pianist. The lower Court found that Gould's publicity rights were descendable and exercisable by the estate, subject to the public interest of the publication of the biography. Noting the difference between privacy rights, which are clearly nondescendable as a dead person cannot be injured through exposure, the Court established that publicity interests are property rights similar to copyright. The Court of Appeal decided the case based on copyright infringements not on misappropriation of personality. However, the Court asserted that copyright in the photographs vested in the photographer, not the subject. This is consistent with the Copyright $A c t,{ }^{68}$ which also provides that moral rights vest with the photographer. Since Gould had expressly consented to the taking of the photographs while alive, he had no proprietary interest. ${ }^{69}$

Through their emphasis on the Gould Court's sidestepping of personality rights issues, some commentators have implied that Gould casts a shadow on the personality rights. ${ }^{70}$ This may be an accurate view as the Court of Appeal stated at the outset in Gould, "it is not necessary to decide the issues in this case on the basis of the relatively new development in tort of appropriation of personality when this case so clearly sounds in intellectual property."71

An important difference between photographs of the kind in Gould, and digital recreations of actors in film, is that obviously the digital three-dimensional images are altered whereas the Gould photos were not. Digital imaging to retouch photos raises a host of other legal issues, such as libel and "false light."72 To address these issues, which is beyond the scope of this article, it becomes necessary to see whether the actor granted permission for photographs taken of her to be altered in any way. Courts have shown that if a photograph is altered enough, as it clearly would be when used to digitally recreate a moving character, it will no longer be the same photograph for which the plaintiff granted use. ${ }^{73}$ Consequently, if an actor granted permission to a studio to alter the film, perhaps for special effects in a particular movie, any footage from that movie might be

(1997), 30 O.R. (3d) 520 (Gen. Div.) [hereinafter Gould].

R.S.C. 1985 , c. C-42.

S.H. Abramovitch, "Misappropriation of Personality" (2000) 33 Can. Bus. L.J. 230 at 236.

M.A. Wilkinson \& C.A. Painter, "Shifting the Balance of Copyright Control for Photographic Works in Canada" (1999) 13 I.P.J. 353 at 374-75.

Gould Estate v. Stoddart Publishing Co. (1998), 39 O.R. (3d) 545 (C.A.) at 547.

See generally L.B.A. Potter, "Altered Realities: The Effect of Digital Imaging Technology on Libel and Right of Privacy" (1995) 17 Hastings Comm. \& Ent. L.J. 495. False light is an American concept, similar to defamation, but the erroneous depiction does not have to be defamatory to sustain liability, but need only be false and cause offence to a person of reasonable sensibilities. See G. Cummins, "Defamation and Invasion of Privacy on the Internet," online: FindLaw <library.Ip. findlaw .com/scripts/getfile.pl?FILE=firms/graycary/gcwf000026> (date accessed: 14 February, 2002).

Potter, ibid. at 509. 
useable to entirely digitally recreate the actor in a later movie. ${ }^{74}$ Of course, most acting contracts would probably provide that any photographs taken are exclusively for use in that particular project.

In addition to these rulings on copyright in the photographs, Gould states that the statutory preclusion of post-mortem personality rights found in the Privacy Acts of British Columbia, ${ }^{75}$ Newfoundland, ${ }^{76}$ and Saskatchewan ${ }^{77}$ had no effect on the common law. The Court concluded that the common law tort of misappropriation of personality should not be influenced by statute. ${ }^{78}$ It is also noteworthy that in Gould the Court avoided the issue of an exact duration of publicity rights for the deceased. However, it established that if any duration were to exist it would certainly be more than the 14 years that had elapsed since Gould's death. Additionally, this case shows that the defendant bears the onus of showing that no misappropriation took place. ${ }^{79}$

The second Canadian case that dealt with a dead person's assertion of personality rights was Horton v. Tim Donut Ltd. ${ }^{80}$ which held that the misappropriation of personality tort did not permit a widow of a deceased hockey player the right to enjoin the use of a picture of the famous athlete. This was because the right to use the picture had been previously granted to the defendant by contract; his right to personality had actually been licensed to the defendants. Consequently, Horton may illustrate the need for actors to provide that the contractual relationship expressly terminates on the death of the celebrity. Horton has also shown that personality rights may be restricted by public policy such as freedom of expression and charitable endeavour. ${ }^{81}$

Perhaps the strongest judicial support for post-mortem misappropriation of personality in any common law nation can be found in a decision by the Jamaican Supreme Court. Robert Marley Foundation v. Dino Michelle Ltd. ${ }^{82}$ recognized the tort applied to deceased musician Bob Marley's face. Clarke J. held that Marley's goodwill was violated when his face was appropriated for commercial purposes. The Court also stated that Bob Marley had the exclusive right, which survives his death, to use his name, likeness or image, which could be exploited for commercial purposes. It is hoped that this case influences courts in the Commonwealth generally. ${ }^{83}$ As one's ability to market one's

Following this reasoning, because Jim Carrey's contract for The Mask (New Line Productions, Inc., 1994) must have allowed for the digital morphing of his face on film, the digital images taken from the movie could be used to recreate Carrey from scratch in another film.

Privacy Act, R.S.B.C. 1996, c. 373.

Privacy Act, R.S.N. 1990, c. P-22.

Privacy Act, R.S.S. 1978, c. P-24.

Gould, supra note 67 at 528 .

Abramovitch, supra note 69 at 239.

(1997), 75 C.P.R. (3d) 451 (Ont. Gen Div.) [hereinafter Horton].

Abramovitch, supra note 69 at 241 .

(12 May 1994) C.L. R. 115/1992 [unreported], as cited by Hylton \& Goldson, infra note 83 [hereinafter Marley].

B. St. Michael Hylton \& P. Goldson, "The New Tort of Appropriation of Personality: Protecting Bob Marley's Face" (1996) 55 Cambridge L.J. 56 at 60. 
image is a property right at life, it should be the same at death. Otherwise the value of the existing contract made while the celebrity is alive would be greatly diminished. ${ }^{84}$

It is difficult to envision how the Canadian tort of misappropriation of personality would be applied to the digital resurrection of deceased actors under Canadian law. The tort was conceived in response to advertising, and as such it might be difficult to apply to a non-commercial, artistic medium such as a film or television program. Some hold that Gould has established that the plaintiff's personality must be in association with sales or advertising, rather than as the subject of a work. This is the so-called "sales v. subject" distinction. ${ }^{85}$ However, many would view films as an equally commercial activity as product advertisement. This distinction may depend on the nature of the film itself: is it a big budget, extensively advertised film that is essentially equivalent to a business venture, or is it primarily the collaborative expression of numerous artists whose objective is creativity? This approach may lead to the problematic conclusion that only nonprofitable films may be considered "artistic." As Susan Abramovitch notes, there is clearly a need for "a more sophisticated approach to the doctrine." 86

\section{Canadian Statutory Protection for Deceased Celebrities}

\section{A. TRADEMARKS}

The Canadian Trade-marks $A c t^{87}$ has also been used to protect the publicity of celebrities. Johnny Carson relied on the Act when the expression "Here's Johnny" was used to advertise a portable toilet, as it suggested a connection with the celebrity. ${ }^{88}$ However, the commonly-used s. $9(1)(\mathrm{k})$ explicitly limits the protection against marks resembling living individuals. ${ }^{89}$

Section 9(1)(l) of the $A c t$ prohibit trademarks which consist of "the portrait or signature of any individual who is living or has died within the preceding thirty years." Unlike s. $9(1)(k)$, which extends to "any matter," s. $9(1)(1)$ only protects portraits or signatures. "Portrait" is not defined in the $A c t$, but it seems possible that it could be extended to include digitally created moving images in film. Digitally created characters are a form of graphic representation, which is clearly the subject matter of trademark law. One commentator has suggested that $s .9(1)(I)$ is so broad that the only certain way to avoid liability is to use a personality who has been dead for at least thirty years. ${ }^{90}$ Still, case

Ibid. at 64 . A studio that could not afford a living actor could avoid hiring him, and merely wait until he died.

ss Supra note 69 at 239.

8. Ibid. at 246.

$87 \quad$ R.S.C. 1985 c. T- 13

8* Carson v. Reynolds (1980), 49 C.P.R. (2d) 57 (F.C.T.D.).

8) Supra note 87. Section 9(1): No person shall adopt in connection with a business, as a trade-mark or otherwise, any mark consisting of, or so nearly resembling as to be likely mistaken for,

$(k)$ any matter that may falsely suggest a connection with any living individual. 
law has shown that to invoke the protection of either ss. $9(1)(k)$ or $9(1)(l)$ the celebrity must have a fairly significant degree of fame. ${ }^{91}$

\section{B. Privacy}

Manitoba, British Columbia, Saskatchewan, and Newfoundland all have Privacy Acts that provide that the use of the name, likeness, or voice of a person for advertising or trade purposes without authorization is illegal. Section 3 of Manitoba's Privacy Act states:

Without limiting the generality of section 2, privacy of a person may be violated

c) by the unauthorized use of the name or likeness or voice of that person for the purpose of advertising or promoting the sale of, or any other trading in, any property or services, or for any other purposes of gain to the user if, in the course of the use, that person is identified or identifiable and the user intended to exploit the name or likeness or voice of that person. ${ }^{92}$

While the statute seems to be aimed at advertising, "any other purpose of gain" could possibly apply to a film if a profit is made. Furthermore, the use of a deceased, digitally recreated actor would still be a violation of this statute, even if the star's name was not used in connection with the film as long as she was still recognizable. The British Columbia Privacy Act expressly deals with look-alikes, prohibiting the use of any likeness of another person "deliberately disguised to resemble to the plaintiff." Strangely, Ontario, which generated $\$ 934$ million through film and television production in 1999, has not enacted a privacy statute. ${ }^{94}$

Manitoba is the only province whose Privacy Act does not expressly state that the protections are extinguished at death. ${ }^{95}$ Manitoba's Privacy Act also contemplates the effect the violation of a person's privacy rights will have on the person's family. ${ }^{96}$ This

See Cooper v. Marks Work Warehouse (1985), 5 C.I.P.R. 194 (T.M.O.B.).

Privacy Act, R.S.M. 1987, c. P-125.

The British Columbia Act (supra note 75) follows the decision Joseph v. Daniels (1986), 4 B.C.L.R. (2d) 239 (S.C.) requiring recognizability.

See Ontario Ministry of Citizenship and Culture, "Support for Ontario's Television Industry," Backgrounder (14 September 2000), online: <www.gov.on.ca/MCZCR/english/about/b 140900.htm> (date accessed: 28 June 2001).

Commentator Brian W. Gray claims that the Manitoba Act establishes a limitation period of two years from the time the plaintiff first becomes aware of the misappropriation, and in no circumstances will the limit be more than four years. According to Gray, "[t]his suggests strongly that the action would not continue after death, since the limitation period is based on the person's awareness." However, there is no evidence of this limitation anywhere in the $\mathrm{ACl}$, and Gray does not give a citation for it. B.W. Gray, "What Price Fame? Personality Rights in Canada and Beyond" (Entertainment, Advertising and Media Law Conference, Osgoode Hall, 23 \& 24 February 1996) Dept. of Continuing Legal Education, Law Society of Upper Canada (1996) 47 at 58.

Supra note 92, s. 4(2). In awarding damages in an action for a violation of privacy of a person, the court shall have regard to all the circumstances of the case including: "b) the effect of the violation of privacy on the health, welfare, social, business or financial position of that person or his family" [emphasis added]. Under s. I "family" means the husband, wife, child step-child, parent, step-parent, brother, sister, half-sister, step-brother and step-sister of a person. So protection will only be extended to one generation. Grandchildren will have no cause of action. 
suggests that the rights may well be descendable, even if for only a limited duration. As yet, there have been no cases that have brought into question the potential descendability of the Manitoba statute.

The Civil Code of Quebec declares that personality rights are inalienable. ${ }^{97}$ Furthermore, the Quebec Code expressly provides that privacy rights are transmissible upon death: "[n]o one may invade the privacy of a person without the consent of the person or his heirs, unless authorized by law."98 Under Quebec law, a person's heirs may claim compensation on behalf of the deceased for actions that took place after that person's death. Article 35 may also cover invasions or encroachments to the reputation of the deceased person that occur after death. This protection should extend, if not to all subsequent generations, at least to immediate family members. ${ }^{99}$ In this sense, the estate of a deceased actor might have a strong case against the use of a synthespian if the action were brought in a Quebec court. An American authority suggests that the jurisdiction of the deceased celebrity's permanent domicile will be the governing law, but the "most significant contacts test" has also been applied to allow actions to be brought in other jurisdictions if the infringing transaction, i.e., the film or advertisement, has taken place there. $^{100}$

Support for deceased person's image in Quebec may derive from similar laws in France, which are moving towards recognizing descendability of publicity rights. ${ }^{101} \mathrm{~A}$ French court held that it is illegal to commercially exploit the image of a deceased celebrity without the prior consent of his or her heirs, but the right to grant this consent cannot be assigned by the heirs to a third party. ${ }^{102}$ This last criteria is odd, as it suggests that only the legal heirs would know their parent's wish regarding the use of his or her publicity. This is particularly difficult to envision if the celebrity had an agent or trusted advisor who would actually be more qualified to decide the ways in which the deceased person would have wanted his or her image used.

Art. 3 C.C.Q. [hereinafter Quebec Code]. The Quebec right of privacy was discussed in the 1998 Supreme Court of Canada decision Aubry v. Editions Vice-Versa Inc., [1998] I S.C.R. 591. The Court held that publication in an arts magazine of a photograph of a teenager, taken in a public place without her permission, infringed her right to her image and her privacy. An artist's right to publish her work is not absolute and cannot include unjustified infringement of the fundamental right of the subject whose image appears in the work. The Court explained that such balancing will always be contextual.

Art. 35 C.C.Q.

Gray, supra note 95 at 63.

V.A. Kovner \& G.M. McCarthy, "The Rights of Heirs of Celebrities in N.Y. Change to Statute Not Likely to Have Significant Effect" (1997) 218:87 N.Y.L.J. Indiana, for example, will allow an action to proceed in its courts even if an infringing advertisement merely enters the state.

E. Logeais \& J-B. Schroeder, "The French Right of Image: An Ambiguous Concept Protecting the Human Persona" (1998) 18 Loy. L.A. Ent. L.J. 511 at 535.

Societe Bonnet v. Societe Cashart United Diffusion Moderne, Court of Appeal $4^{c}$ ch. Paris, 7 June 1983 as cited by Logeais \& Schroeder, ibid. 


\section{COPYRIGHT}

The Canadian Copyright $\mathrm{Act}^{103}$ affords little protection to deceased actors who are digitally resurrected in film. ${ }^{104}$ Still, commentator Robert Howell compares the statutory rights of privacy to Canadian copyright law's moral rights, which reflect the way in which a work is used. Moral rights are proprietary, but they also have a personal characteristic as they involve the dignity of the author and the integrity of her work. ${ }^{105}$ Like the ordinary economic rights of copyright, moral rights are protected for fifty years after the death of the author, and they are explicitly descendable. ${ }^{106}$ While this may seem helpful, it is important to remember that copyright protects the work; whereas personality rights protect the persona. ${ }^{107}$ It would be difficult to perceive a digitally resurrected actor as a work of that actor, as he would have had nothing to do with the creation of the images. Many actors would probably disagree with this view. There might be economic or moral rights in the original photographs from which the digital image is created, but those would belong to the photographer. Moreover, it is not customary to grant actors or models economic copyright interests in the films or pictures in which they appear. ${ }^{108}$

American advertising lawyer Rick Kurnit believes that the law regarding digital actors will come down to the size of the synthespian's role. In contrast to the view of Kunath, who suggests that large roles will be protected and cameos will not, Kurnit believes that a substantial role will raise a concern of "ripping-off" the performer who would have normally been paid, whereas a small role would be acceptable. ${ }^{109}$ Yet it is unclear if Kurnit is speaking of replicas of dead actors or actors in general. "Ripping off" may be an inappropriate term if the actor is dead and cannot play the role. But if he is still alive, and could possibly be hired but the digital recreation is cheaper, then "ripping-off" might be a valid assessment. This view is consistent with Martin Jr. and Beard. Consequently the axiom would be, dead actors must have large roles, and living actors must have small ones.

\section{SOLUTIONS}

Several schemes have been proposed that could diminish the conflict between an estate's interest in the deceased celebrity's publicity rights and the public's interest in enjoying the films that the digital innovation offers. Kunath feels that the right of publicity should be eliminated, as it gives celebrities and their estates an "obscene windfall" by compensating them for work which they have not done. ${ }^{110}$

Supra note 68.

Howell, supra note 56 at 505 . Howell does not detail the $\mathrm{Act}$ 's protection of the filmmakers who resurrect them.

Copyright Act, supra note 68 , s. 14.1 .

Ibid., ss. 14.2(1) and 14.2(2).

Howell, supra note 56 at 505.

Ibid. at 506.

M. Gollom, "Celebrities Fight to Save Face," online: The Ottawa Citizen On-line, <www.ottawa citizen.com/national/980413/1639186.html> (date accessed: 28 June 2001).

Kunath, supra note 20 at 897. 
Is the celebrity really responsible for her own fame, or is the film and television industries' ability to exploit talent through all technological options the reason for the scope and worth of a celebrity's fame? ${ }^{\prime \prime \prime}$

This raises fundamental concepts of intellectual property law such as goodwill and reputation. It is precisely because actors have put so much effort into their work in the early stages of their career, albeit with the help of talented writers and directors, that they have so much worth later on. Very few celebrities owe their entire market worth, or even a significant portion thereof, to the special effects which have been used to enhance their presence in a film.

Similarly, Beard suggests a "minimalist approach" where heirs of deceased celebrities are protected against only an egregious and "knowingly false" portrayal. ${ }^{12}$ This could lead to the most difficult judicial analysis of all, determining whether producers or directors reasonably knew if a portrayal would be patently against the spirit of the deceased celebrity's living career. This would be something that the celebrity would never have done in life, such as a religious figure known for his piety appearing in a pornographic role, or Charleton Heston appearing in an anti-NRA commercial. This raises questions of a duty to inform oneself of a celebrity's past roles and such other complex considerations. It is likely that Beard means that a Court should be mindful of open abuse and ridicule, factors which influenced the Astaire Court.

In contrast, commentator Jeanne McManus holds that parallel purposes of publicity rights and copyright, namely the encouragement of individual creative effort through economic incentive, mandates a continuation of publicity rights beyond the grave..$^{1 / 3}$ This view may be flawed, however, as the encouragement of creative effort in filmmaking would allow for greater freedom to develop and use digital technology, if not as a new art form, then at least as a new genre of film. After all, a celebrity's potential for creative use of his own persona ends at death, whereas others could use it indefinitely.

Kunath's view was adopted by the Court in Memphis Development Foundation v. Factors Etc., Inc., ${ }^{114}$ a case that dealt with Elvis Presley's likeness being used in advertising. The Court ruled that the desire to exploit one's fame for the financial advantage of one's heirs offered no significant motivation for effort as an actor. ${ }^{115}$ But as Ben C. Adams comments, this argument could apply to any successful, lucrative career. He adds that it would make more sense that the celebrity's heirs benefit rather than an outside third party. ${ }^{116}$ Still, from a standpoint of pure intellectual effort, a digital effects technician who recreates a dead actor has devoted creative labour to the activity, whereas

lbid. at 901.

Beard, supra note 47 at 26.

J.A. McManus, "Famous Person's Right of Publicity is Descendable" Note (1983) 14 Seton Hall L. Rev. 190 at 199.

616 F.2d 956 (6th Cir. 1980).

The Court also cited practical problems of determining exactly how long the right would last after death.

Adams, supra note 22 at 1261 . 
the heirs have done nothing. Of course the dead actor would probably rather have any monetary reward go to his family first.

Clearly favouring the creativity of the writer/director at the expense of the star, Kunath proposes a compulsory licensing scheme where personalities would be compelled to accept a certain number of offers for digital representations of them in film. Exclusive licences would not be permitted, and celebrities would be able to sell their post-mortem rights before they die. ${ }^{117}$ As Giacoppo points out, this scheme is problematic as it leaves a dead celebrity open for exploitation in unwanted projects. A studio could submit an undesirable offer at the end of the requisite term, and if the estate had not accepted the statutory minimum, it would be forced to license the actor's likeness. Furthermore, less popular stars would be more vulnerable because they would receive fewer offers, and be forced to accept exploitative requests. ${ }^{118}$ Pornography is the worst case scenario, and courts should prohibit pornographic uses as a matter of course.

Despite the flaws of the compulsory licensing scheme, it makes sense that post-mortem rights be limited to situations where a contract exists, or else there would be no specific indication that the person had any intention to transfer the benefits of his personality to his heirs. ${ }^{119}$ In this way, the right to create digital representations of a deceased actor should not form part of the residue of a person's estate, nor should it be distributed according to the rules of intestacy. If the actor did not expressly desire the right to be administered by her estate, then we may be tempted to assume that she did not value her persona sufficiently that it be taken from the hands of the potentially creative public domain. However, this could be unfair to a young actor who dies suddenly without a will, or for any celebrity who might not know that it is possible to bequeath the rights to their likeness. Clearly, failure to make testamentary provisions for one's personality rights does not, strictly speaking, mean that the actor did not value her persona sufficiently.

Celebrities who are concerned with the use of their image after they have died could use contractual or testamentary arrangements to secure their publicity rights. As Giacoppo argues, such an open licensing scheme should mirror the free market, which pays living actors in high demand more than those in lower demand. This would compel studios to implement high calibre digital effects to support their financial interests with quality synthespain performances. ${ }^{120}$ An actor's estate, or even the third party to whom he has assigned his post-mortem rights, would decide which roles were appropriate and the fee required. ${ }^{121}$ It would be in their purview to decide, subject to any contractual arrangements with the deceased celebrity, if they do not wish any digital reproductions at all. However, in keeping with the tradition of international copyright law and the limitation seen in the California Celebrity Protection Act, the right to license one's image after death should be limited to a period of time, perhaps 70 years. At this point the

\footnotetext{
$117 \quad$ Kunath, supra note 20 at 903.

IIx Giacoppo, supra note 2 at 250-51.

119) Felcher \& Rubin, supra note 25 at 1131.

120 Giacoppo, supra note 2 at 249.

121 This is contrary to the French view, but in keeping with the Canadian Horton decision, supra note 80 .
} 
person's image should fall into the public domain. This seems to be the fairest balance between protecting the interest of the actor and fostering artistic creativity in film.

If descendability of publicity rights in film is recognized, it may only be for a limited duration, as in copyright. The limited duration is meant to mirror the "waning cycle" of a celebrity's fame and marketability. ${ }^{122}$ However, it is possible that digital animation could end this cycle, allowing a celebrity to live forever in the movies. While public appearances, talk shows, and media attention are undoubtedly part of that which perpetuates a star's fame, it is the continued release of an actor's films, especially quality ones, that make him a hot commodity. Consequently, this new digital existence requires that we re-evaluate the traditional concept of placing limits on the right of publicity protection. Instead, the market should dictate when the protection is no longer deserved. This will be the time at which a celebrity's commercial value is less than the transactional cost of protection, i.e., the licence fee exceeds its worth. ${ }^{23}$

If a licence is not obtained for a digital actor, courts should be free to weigh the originality and creativity compared to the exploitative nature of the film when deciding liability. The case Washington v. Brown \& Williamson Tobacco Corp. ${ }^{124}$ could shed some light on a court's decision in the absence of a licence. If the living actor refused this role or one similar to it during his lifetime, then a violation of the right should be found. ${ }^{125}$ Strictly speaking, a synthespian is nothing more than a technological lookalike, and the Onassis and White cases have shown that look-alikes will not be tolerated. If the real actor has refused the role, then this wish must be extended beyond the grave. Of course, the concept of role refusal helps only for a limited number of projects. Similarly, if the studio approached the estate and was refused but used the image anyway, then liability should be found regardless of the creative, non-exploitative nature of the role.

Damages for the infringement of the post-mortem right of publicity through a digitally resurrected actor should be the amount the estate would have been paid if the studio had received permission to use the digital actor. ${ }^{126}$ This rate could be difficult to ascertain unless there had been previous licences issued by the estate for digital recreations of the celebrity. The court must also engage in the difficult weighing of the creativity and the degree of exploitation in the role to see if there should be additional compensation for damage to reputation.

In addition to any common law or statutory damages, the Screen Actors Guild, or other collective society might impose their own fines on a studio guilty of using an unauthorized synthespian. Some acting unions require consent to be obtained from the estates of deceased persons for use of that person's likeness in film or television clips. The

Martin Jr., supra note 7 at 131.

Ibid. at 132.

223 U.S.P.Q. 1116 (E.D. P.A. 1984).

If an actor who is very similar in appearance to a known celebrity is used for a role, and the celebrity had been approached for the role and refused, then a violation should be found.

Weinstein, supra note 1 at 271 . 
Screen Actors Guild forbids reuse of an actor's picture or voice in another field or medium without consent of the performer. If consent is not obtained, the performer is entitled to three times the amount originally paid. ${ }^{127}$ The Screen Actors Guild should include explicit provisions in their standard contracts to provide similar protection for deceased celebrities, allowing descendants to give consent. Again, damages of this sort would be difficult to ascertain in the case of a deceased celebrity whose digital "rate" may not yet be established. The rate he had been paid while alive could be applied, but it might be grossly inaccurate if the celebrity had died more than ten years previous. Regardless of these difficulties, the Screen Actors Guild should devise its own rules regarding the use of synthespians of dead stars. A move by this organization might increase the responsiveness of the judicial bodies and legislatures to the legal problems associated with the developing technology.

To facilitate the administration of such issues, some commentators believe that there should be a national regime for protecting publicity rights, both before and after death. In Canada this can be done federally with intellectual property rights and provincially through the privacy statutes. This would prevent forum shopping, eliminate jurisdictional difficulties, and decrease transaction costs. ${ }^{28}$ The American Bar Association has undertaken a study to examine the utility of a federal publicity protection scheme, as has a committee of the International Trademark Association. ${ }^{129}$

\section{CONCLUSION}

Digital imaging technology will soon make it possible to resurrect deceased actors to star in full-length feature films, much as they have already begun to appear in commercials. Recognizing the severe legal and moral implications of a third party using a person's fame for profit, several American states and Canadian provinces have enacted legislation that protects the deceased against unauthorized use of their likenesses for advertising purposes. California's Celebrity Protection Act is a positive move towards addressing the concerns of celebrities' heirs, extending rights to 70 years and covering any infringement that occurred within the state. Still, courts have been unwilling to grant a post-mortem right of privacy for many non-commercial purposes, such as films and biographies. In fact, many creative categories have explicit exemptions under the important and influential California $\mathrm{Act}$.

Canada's tort of misappropriation of personality may well be similarly limited. In addition to demonstrating the Court's reluctance to consider the tort, Gould has already shown that this doctrine does not apply after death in the cases of public interest, such as biographies. It is likely that films and other creative media may also be exempt. Still, the Jamaican Marley decision established that the tort can apply to deceased persons. The Trade-marks Act could offer post-mortem protection for certain deceased celebrities under

Screen Actors Guild 1996-1999 Digest of Basic Rates and Conditions for Industrial Educational Films and Videotapes, s. 27, online: <www.sag.com/industrial-education.html> (date accessed: 25 October 2001).

Martin Jr., supra note 7 at 133.

Beard, supra note 11. 
a potentially expanded definition of portrait. Furthermore, Manitoba and Quebec have granted a statutory post-mortem right of privacy, but this may only apply to commercial endeavours. Again, cases and statutes seem to contemplate advertising purposes only, and consequently, it is uncertain how the law will apply to films.

The tension underlying the debate over synthespians concerns the individual's right to profit from his persona, and filmmakers' right to express themselves creatively. Consequently, any future film projects that star deceased actors should be as original as possible and, at the same time, respectful to the celebrity's memory. Licensing schemes have been suggested, which would allow the estate to choose projects based on fee and suitability to the deceased actor's wishes. As lawyers we know that a person's rights are immeasurably important, and as moviegoers we must hope that actors will recognize the value of their personas and be willing to license their resurrection in films. 